\title{
THERMAL AND OPTICAL PROPERTIES OF NEW POLY(AMIDE-IMIDE)- NANOCOMPOSITE REINFORCED BY LAYER SILICATE BASED ON CHIRAL $N$-TRIMELLITYLIMIDO-L-VALINE
}

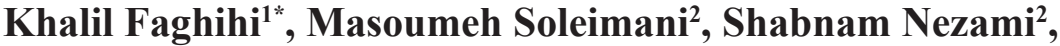 \\ Meisam Shabanian' \\ ${ }^{1}$ Organic Polymer Research Laboratory, Department of Chemistry, Faculty of Science, \\ Arak University, Arak 38156-8-8349, Iran \\ ${ }^{2}$ Polymer Research Laboratory, Department of Chemistry, Faculty of Science, \\ Islamic Azad University, Arak Branch, Arak, Iran \\ k-faghihi@araku.ac.ir
}

Two new samples of poly(amide-imide)-montmorillonite reinforced nanocomposites containing $N$-trimellitylimido-L-valine moiety in the main chain were synthesized by a convenient solution intercalation technique. Poly(amide-imide) (PAI) 5 as a source of polymer matrix was synthesized by the direct polycondensation reaction of $N$-trimellitylimido-L-valine (3) with 4,4'-diaminodiphenyl ether 4 in the presence of triphenyl phosphite (TPP), $\mathrm{CaCl}_{2}$, pyridine and $N$-methyl-2-pyrrolidone (NMP). Morphology and structure of the resulting PA-nanocomposite films (5a) and (5b) with 10 and $20 \%$ silicate particles were characterized by FTIR spectroscopy, X-ray diffraction (XRD) and scanning electron microscopy (SEM). The effect of clay dispersion and the interaction between clay and polymeric chains on the properties of nanocomposite films were investigated by using UV-Vis spectroscopy, thermogravimetric analysis (TGA) and water uptake measurements.

Keywords: $N$-trimellitylimido-L-valine moiety; poly(amide-imide); montmorillonite; nanocomposite; optical and thermal properties

\section{ТЕРМИЧКИ И ОПТИЧКИ ОСОБИНИ НА НОВ ПОЛИ(АМИД-ИМИД)-НАНОКОМПОЗИТ ЗАСИЛЕН СО СЛОЈ ОД СИЛИКАТ НА БАЗА ОД ХИРАЛЕН N-ТРИМЕЛИТИЛИМИДО-L-ВАЛИН}

Со погоден метод со интеркалација беа добиени два нови примерока од поли(амид-имид)монтморилонит засилени со нанокомпозити кои во главната низа содржат групи на тримелитилимидо-L-валин. Поли(амид-имидот) (PAI) 5 кој служи како полимерен матрикс беше синтетизиран со директна реакција на поликондензација на тримелитилимидо-L-валин (3) co 4,4'-дифенилетер 4 во присуство на трифенилфосфит (ТPР), $\mathrm{CaCl}_{2}$, пиридин, $N$-метил-2-пиролидон (NMP). Морфологијата и структурата на добиените РА нанокомпозитни филмови (5a) и (5b) со 10 и 20 \% силикатни честички беа карактеризирани со FTIR-спектроскопија, рендгенска дифракција (XRD) и скенирачка електронска микроскопија (SEM). Со ултравиолетова спектроскопија (UV-Vis), термогравиметриска анализа (TGA) и атсорпција на вода беа испитувани влијанието на дисперзијата на глината и интеракцијата на глината со полимерните низи врз својствата на нанокомпозитните филмови.

Клучни зборови: $N$-тримелитилимидо-L-валин; поли(амид-имид); монтморилонит; нанокопомпозит; оптички и термички својства. 


\section{INTRODUCTION}

Polymer-clay nanocomposites typically exhibited mechanical, thermal and gas barrier properties, which are superior to those of the corresponding pure polymers [1-9]. Unique properties of the nanocomposites are usually observed when the ultra fine silicate layers are homogenously dispersed throughout the polymer matrix at nanoscale. The uniform dispersion of silicate layers is usually desirable for maximum reinforcement of the materials. Due to the incompatibility of hydrophilic layered silicates and hydrophobic polymer matrix, the individual nanolayers are not easily separated and dispersed in many polymers. For this purpose, silicate layers are usually modified with an intercalating agent to obtain organically modified clay prior to use in nanocomposite formation [10-11]. Also, aromatic polyimides are well recognized as a class of high performance materials due to their remarkable thermal and oxidative stabilities and excellent electrical and mechanical properties for long time periods of operation [10-12]. Unfortunately, strong interaction between polyimide chains and their rigid structure make them intractable. Poor thermoplastic fluidity and solubility are the major problems for wide application of polyimides. Thus, to overcome these processing problems various approaches have been carried out by incorporating flexible units such as $-\mathrm{NHCO}-,-\mathrm{O}_{-}$, and $-\mathrm{SO}_{2}-$, and some of which are commercialized [12-14]. Among them, polyamide-imide (PAI) is the most successful material, which combines the advantages of hightemperature stability and processability [15-22]. In this article two PAI-nanocomposite films with 10 and $20 \%$ silicate particles containing chiral $\mathrm{N}$-trimellitylimido-L-valine moiety in the main chain was prepared by using a convenient solution intercalation technique.

\section{EXPERIMENTAL}

\subsection{Materials}

Trimellitic dianhydride, L-valine, 4,4'-diaminodiphenyl ether, acetic acid, triphenyl phos- phite (TPP), $\mathrm{CaCl}_{2}$, pyridine and $N$-methyl-2pyrrolidone (NMP) were purchased from Merck Chemical Company and were used without previous purification. ${ }^{1} \mathrm{H}-\mathrm{NMR}$ spectrum was recorded on a Bruker $300 \mathrm{MHz}$ instrument (Germany). Fourier transform infrared (FTIR) spectra were recorded on Galaxy Series FTIR 5000 spectrophotometer (England). UV-visible spectra were recorded at $25{ }^{\circ} \mathrm{C}$ in the $250-700 \mathrm{~nm}$ spectral regions with a Perkin Elmer Lambda 15 spectrophotometer in NMP solution using cell lengths of $1 \mathrm{~cm}$. Thermal Gravimetric Analysis (TGA and DTG) data were taken on a Mettler TA4000 System under $\mathrm{N}_{2}$ atmosphere at a rate of $10{ }^{\circ} \mathrm{C} / \mathrm{min}$. The morphology of nanocomposite film was investigated on Cambridge S260 scanning electron microscope (SEM).

\subsection{Monomer synthesis}

$N$-Trimellitylimido-L-valine 3 was prepared according to a typical procedure was shown in Scheme 1 [23].

\subsection{Polymer synthesis}

Into a $100 \mathrm{ml}$ round bottomed flask a mixture of $N$-trimellitylimido-L-valine $3(0.002 \mathrm{~mol})$, 4,4'-diaminodiphenyl ether 4 (0.002 mol), $0.60 \mathrm{~g}$ of calcium chloride, $1.0 \mathrm{ml}$ of triphenyl phosphite, $1.0 \mathrm{ml}$ of pyridine and $4.0 \mathrm{ml}$ NMP was placed (Scheme 2). The mixture was heated for $1 \mathrm{~h}$ at $60{ }^{\circ} \mathrm{C}, 2 \mathrm{~h}$ at $90^{\circ} \mathrm{C}$ and then refluxed at $130{ }^{\circ} \mathrm{C}$ for $8 \mathrm{~h}$ until a viscous solution was formed. Then it was cooled to room temperature and $30 \mathrm{ml}$ of methanol was added to the reaction mixture. The formed precipitate was filtered off and washed with methanol. The resulting polymer $\mathbf{5}$ was dried under vacuum. The inherent viscosity of this soluble PA 5 was $0.42 \mathrm{dl} / \mathrm{g}$.

\subsection{PAI-nanocomposite synthesis $\mathbf{5} \boldsymbol{a}$ and $\mathbf{5} \boldsymbol{b}$}

PAI-nanocomposites $\mathbf{5 a}$ and $\mathbf{5 b}$ were produced by solution intercalation method, in two different amounts of organoclay particles (10 and 
20-wt.\%). The appropriate amounts of PAI solution in NMP were mixed to yield particular nanocomposite concentrations. To control the dispersibility of organoclay in poly(amide-imide) matrix, constant stirring was applied at $25^{\circ} \mathrm{C}$ for $24 \mathrm{~h}$. Nanocomposite films were cast by pouring the solutions for each concentration into petri dishes placed on a leveled surface followed by the evaporation of solvent at $70{ }^{\circ} \mathrm{C}$ for $12 \mathrm{~h}$. Films were dried at $80{ }^{\circ} \mathrm{C}$ under vacuum to a constant weight. Scheme 3 shows the flow sheet diagram and synthetic scheme for PAI-nanocomposites film $\mathbf{5 a}$ and $\mathbf{5 b}$.

\subsection{The water absorption analysis}

The water absorption of PAI-nanocomposite films was carried out using a procedure described in ASTM D570-81 [24]. The films were dried in a vacuum oven at $80{ }^{\circ} \mathrm{C}$ to a constant weight and then weighed to get the initial weight $\left(\mathrm{W}_{\mathrm{o}}\right)$. The dried films were immersed in deionized water at $25^{\circ} \mathrm{C}$. After $24 \mathrm{~h}$, the films were removed from water and then they were quickly placed between sheets of filter paper to remove the excess water and films were weighed immediately. The films were again soaked in water. After another $24 \mathrm{~h}$ soaking period, the films were taken out, dried and weighed for any weight gain. This process was repeated again and again until the films almost attained the constant weight. The total soaking time was $168 \mathrm{~h}$ and the samples were weighed at regular $24 \mathrm{~h}$ time intervals to get the final weight $\left(\mathrm{W}_{\mathrm{f}}\right)$. The percent increase in weight of the samples was calculated by using the formula $\left(\mathrm{W}_{\mathrm{f}}-\mathrm{W}_{\mathrm{o}}\right) / \mathrm{W}_{\mathrm{o}}$.

\section{RESULTS AND DISCUSSION}

\subsection{Monomer synthesis}

$\mathrm{N}$-Trimellitylimido-L-valine $\mathbf{3}$ was synthesized by the condensation reaction of one equivalent of trimellitic anhydride 1 with one equivalent of L-valine $\mathbf{2}$ in an acetic acid solution (Scheme 1).

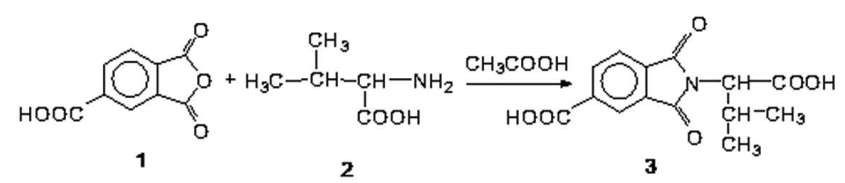

Scheme 1. Synthetic route of $\mathrm{N}$-trimellitylimido-L-valine $\mathbf{3}$

The chemical structure and purities of diacid 3 was also confirmed by NMR spectroscopy. The ${ }^{1} \mathrm{H}-\mathrm{NMR}$ spectrum of diacid $\mathbf{3}$ was shown in Figure 1. The peak relevant to O-H carboxylic acid groups appeared at $13.40 \mathrm{ppm}$. The doublet appearing between $4.48-4.50 \mathrm{ppm}$ was assigned to the $\mathrm{CH}(\mathrm{e})$ protons at the chiral center. The peaks between 0.82-1.08 ppm were assigned to the aliphatic $\mathrm{CH}_{3}(\mathrm{~g}, \mathrm{~h})$ groups. The multiplet centered at $2.58 \mathrm{ppm}$ corresponds to the $\mathrm{CH}(\mathrm{f})$ proton.

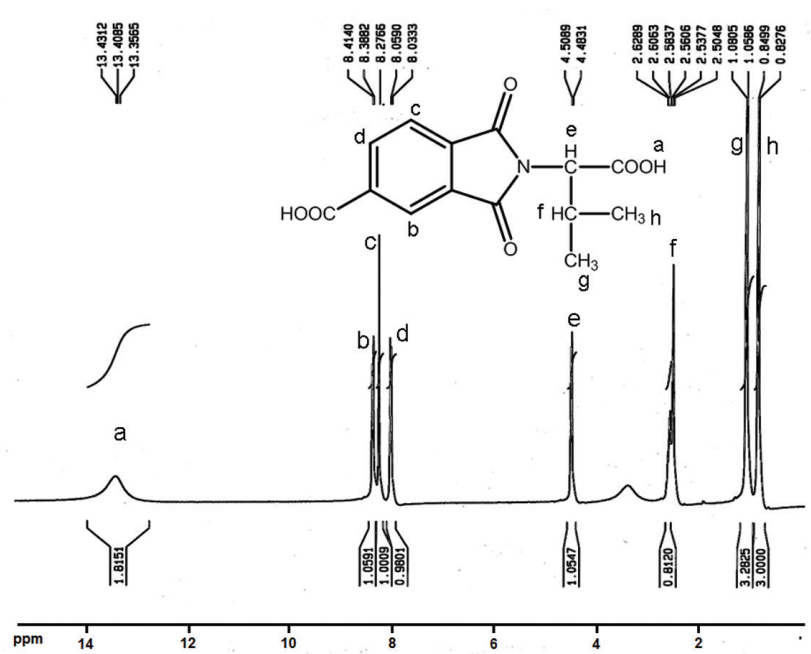

Fig. 1. ${ }^{1} \mathrm{H}-\mathrm{NMR}$ spectrum of diacid 3

\subsection{Polymer synthesis}

Poly(amide-imide)s 5 were synthesized by the direct solution polycondensation reaction of an equimolar mixture of diacid $\mathbf{3}$, an equimolar mixture of diamine 4 by using triphenyl phosphite (TPP) and pyridine as condensing agents (Scheme 2). PAI 5 was obtained in good yield (96\%) and inherent viscosity $\left(0.42 \mathrm{dLg}^{-1}\right)$. The structure of resulting polymer $\mathbf{5}$ was confirmed 
as PAI by using FTIR spectroscopy and elemental analyses. The resulting polymer have absorption band between 1776 and $1665 \mathrm{~cm}^{-1}$ due to imide and amide carbonyl groups. Absorption bands around $1384 \mathrm{~cm}^{-1}$ and $719 \mathrm{~cm}^{-1}$ demonstrated the presence of the imide heterocyclic absorption in these polymers. Also absorption band of amide group appeared at $3338 \mathrm{~cm}^{-1}$ (N-H stretching). The elemental analysis value of the resulting polymer was in good agreement with the calculated values for the proposed structure.<smiles>CC(C)C(C(=O)O)N1C(=O)c2ccc(Nc3ccc(Oc4ccc(NC(C)(C)C)cc4)cc3)cc2C1=O</smiles>

Scheme 2. Synthetic route of PAI 5

\subsection{PAI-nanocomposite films}

PAI-nanocomposite films were transparent and yellowish brown in color. The incorporation of organoclay changed the colour of films to dark yellowish brown. Moreover, a decrease in the transparency was observed at higher clay contents. Scheme 3 shows the flow sheet diagram and synthetic scheme for PAI-nanocomposite films $\mathbf{5 a}$ and $\mathbf{5 b}$.

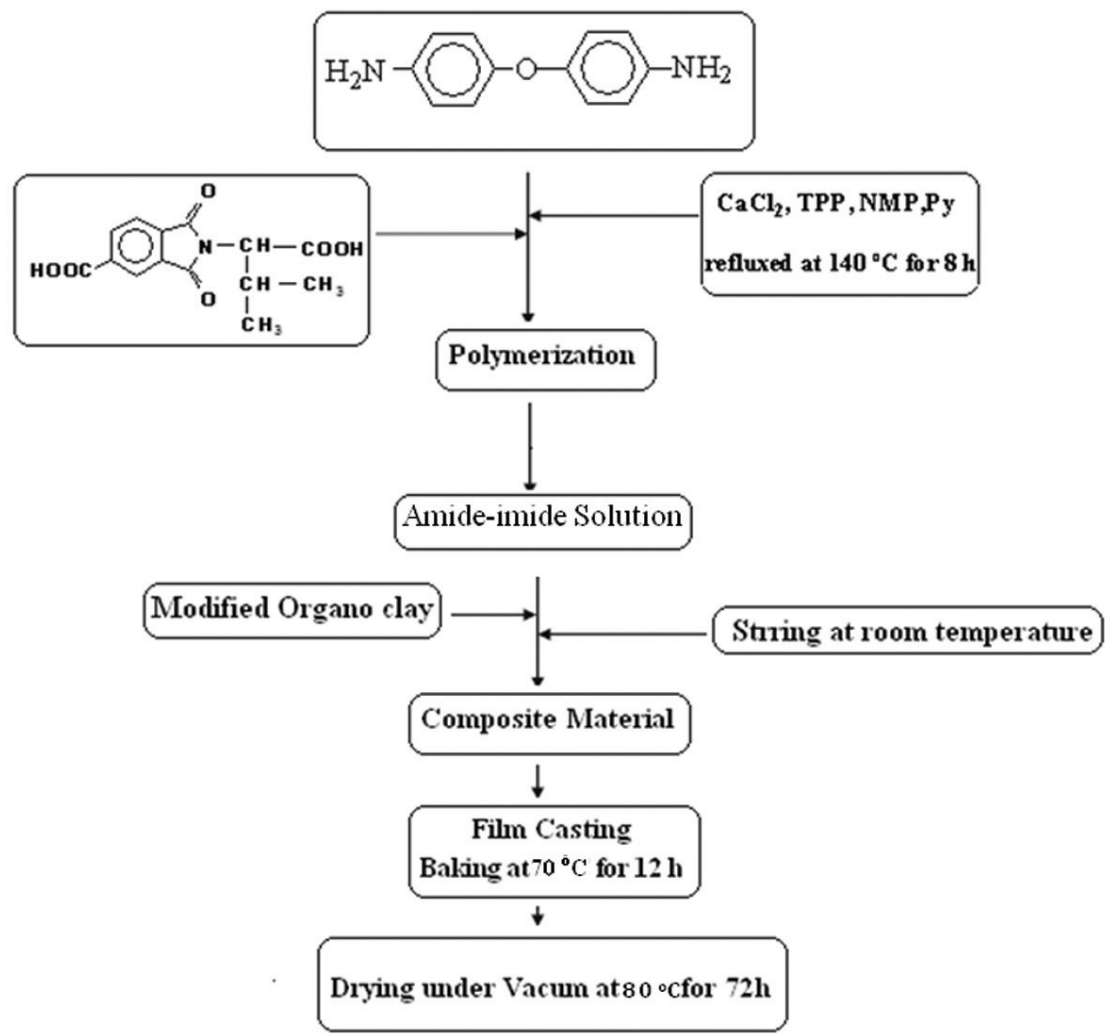

Scheme 3. Flow sheet diagram for the synthesis of PAI-nanocomposites film $\mathbf{5 a}$ and $\mathbf{5 b}$ 


\subsection{Characterization}

FT-IR spectroscopy analyses

FT-IR spectroscopy spectra of PAI-nanocomposite films PAI and PAI-nanocomposite $5 \mathrm{~b}$ showed the characteristic absorption bands of the Si-O, Al-O and Mg-O moieties at 1072, 514 and $450 \mathrm{~cm}^{-1}$, respectively (Fig. 2). The incorporation of organic groups in PAI-nanocomposite films was confirmed by the presence of peaks a ${ }^{\circ} \mathrm{t} 1770,1720,1390,725$ (imide rings) and $1680 \mathrm{~cm}^{-1}$ (amide carbonyl group).
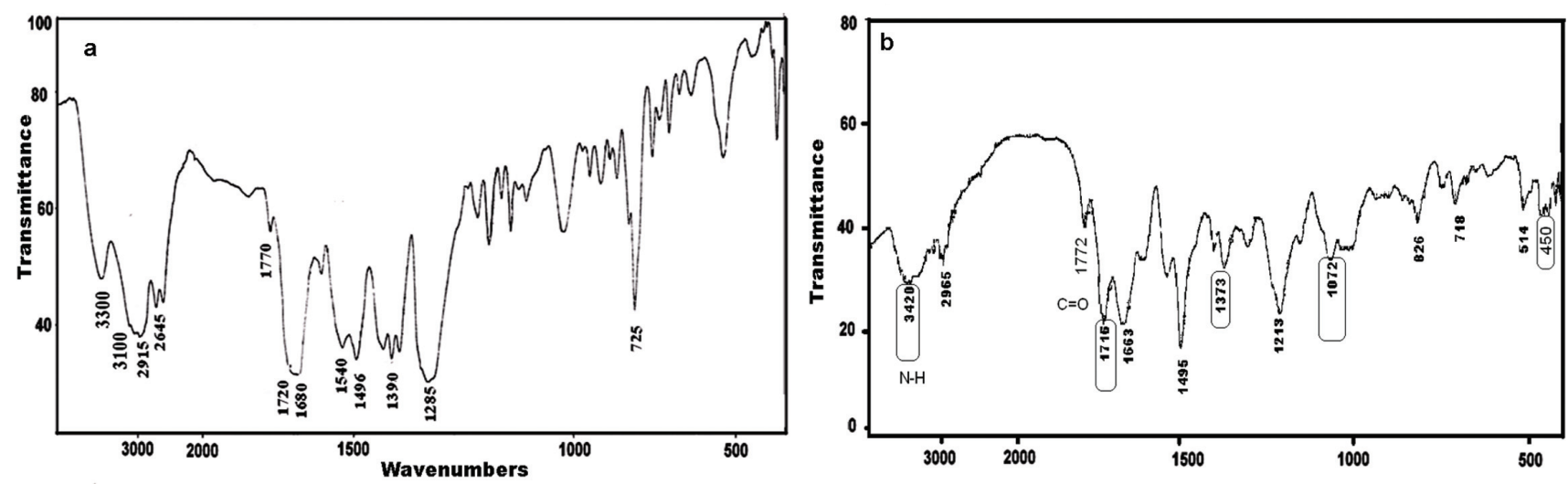

Fig. 2. FT-IR spectroscopy spectra of PAI (a) and PAI-nanocomposite films $\mathbf{5 b}$ (b)
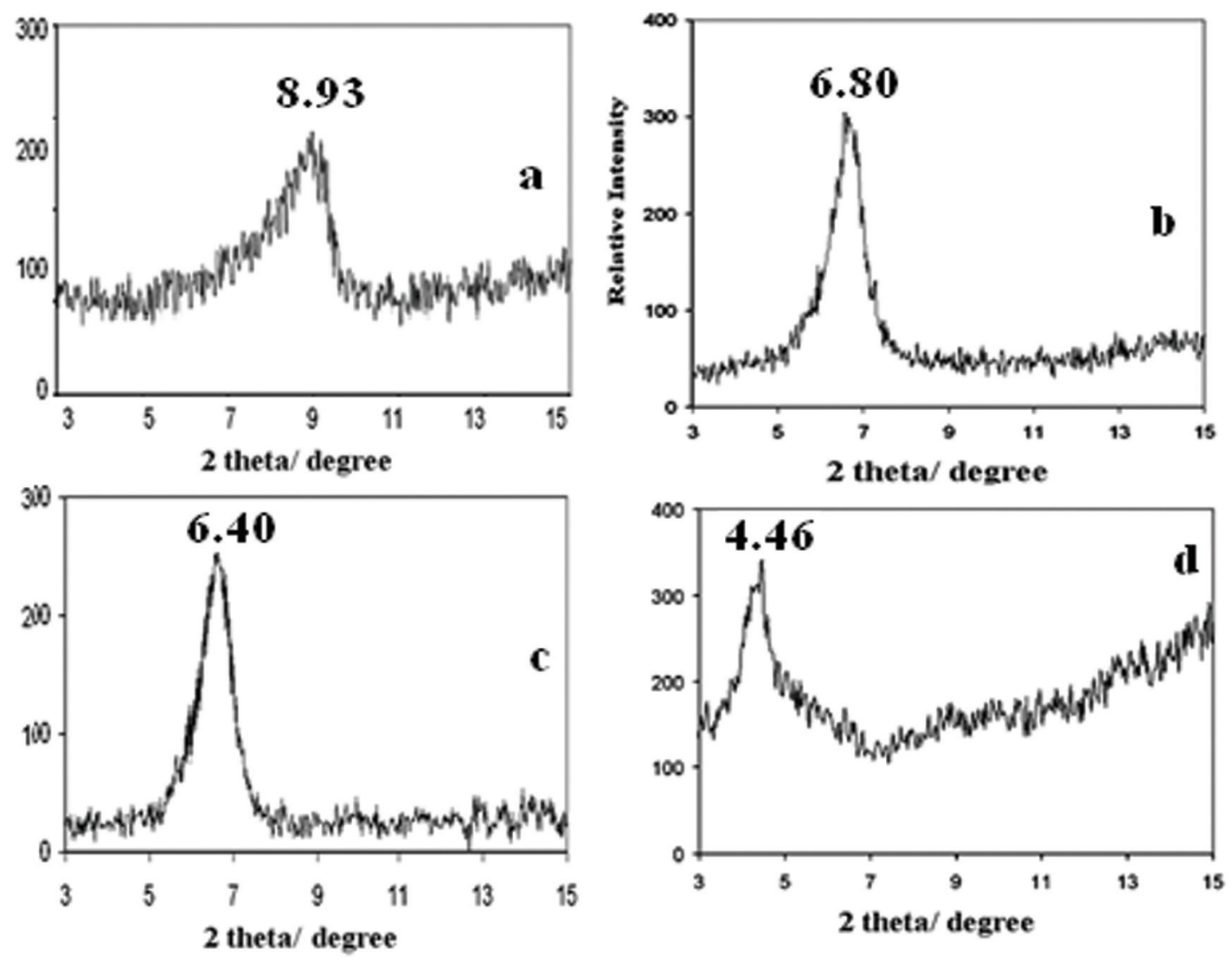

Fig. 3. X-ray diffraction patterns of Cloisite ${ }^{\circledR} \mathrm{Na}^{+}$(a), Organoclay (b), PAI-nanocomposite films $\mathbf{5 a}$ (c) and $\mathbf{5 b}$ (d) 


\section{$X$-ray diffraction analysis}

Figure 3 shows the XRD patterns of PAI-nanocomposite films $\mathbf{5 a}$ and $\mathbf{5 b}$ containing 10 and $20-w t . \%$ of silicate particles. The Cloisite $^{\circledR} \mathrm{Na}$ gives a distinct peak around $2 \theta$ equal to $8.93^{\circ}$, which corresponds to a basal spacing of around $1.00 \mathrm{~nm}$. The organically employed for the preparation of nanocomposites has a typical peak at $2 \theta$ equal to $6.80^{\circ}$ $(1.491 \mathrm{~nm})$ increased d-spacing. When the amount of organoclay increased (10 and 20 wt.\%) in the nanocomposites, small peaks appeared at $2 \theta=6.40^{\circ}$ and $4.46^{\circ}$ corresponding to d-spacing, 1.623 and $1.522 \mathrm{~nm}$, respectively. These results indicated significant expansion of the silicate layer after insertion PAI chains. This is direct evidence that PAI-nanocomposites have been formed as the nature of intercalating agent also affects the organoclay dispersion in the polymer matrix. Usually there are two types of nanocomposites depending upon the dispersion of clay particles. The first type is an intercalated polymer clay nanocomposite, which consists of well-ordered multi layers of polymer chain and silicate layers a few nanometers thick. The second type is an exfo- liated polymer-clay nanocomposite, in which there is a loss of ordered structures due to the extensive penetration of polymer chain into the layer silicate. Such part would not produce distinct peaks in the XRD pattern [25]. In our PAI-nanocomposite films there are coherent XRD signal at $6.40^{\circ}$ and $4.46^{\circ}$ related to 10 and 20 wt.\% nanocomposite films respectively.

\section{Scanning electron microscopy}

The surface morphology of the PAInanocomposite films prepared by solution intercalation technique is compared by SEM analyses. Figure 4 shows the morphological images of 10 and 20 wt.\% nanocomposite films respectively. Nanocomposite films have a very homogeneous distribution with no preferential accumulation of silica in any region across the films. The micrographs also indicate the presence of interconnected silica domains in the continuous polyamide phase, which demonstrates better compatibility between smaller silica nanoparticles and the PAI in the nanocomposite films.



$100 \mathrm{~nm}$



$100 \mathrm{~nm}$

Fig. 4. Scanning electron micrographs of PAI-nanocomposite films $\mathbf{5 a}$ (a) and $\mathbf{5 b}$ (b) 


\section{Optical clarity of PAI-nanocomposite films}

Optical clarity of PAI-nanocomposite films containing 10 and $20 \mathrm{wt} \%$ clay platelets and neat PAI was compared by UV-Vis spectroscopy in the region of $300-800 \mathrm{~nm}$. Figure 5 shows the UV-Vis transmission spectra of pure PAI and PAI-nanocomposite films containing 10 and $20 \mathrm{wt} \%$ clay platelets. These spectra show that the UV-Visible region $(250-800 \mathrm{~nm})$ is affected by the presence of the clay particles and exhibiting low transparency reflected to the primarily intercalated composites. Results shows that the optical clarity of PAI-nanocomposite films system is significantly lower the neat PAI system.

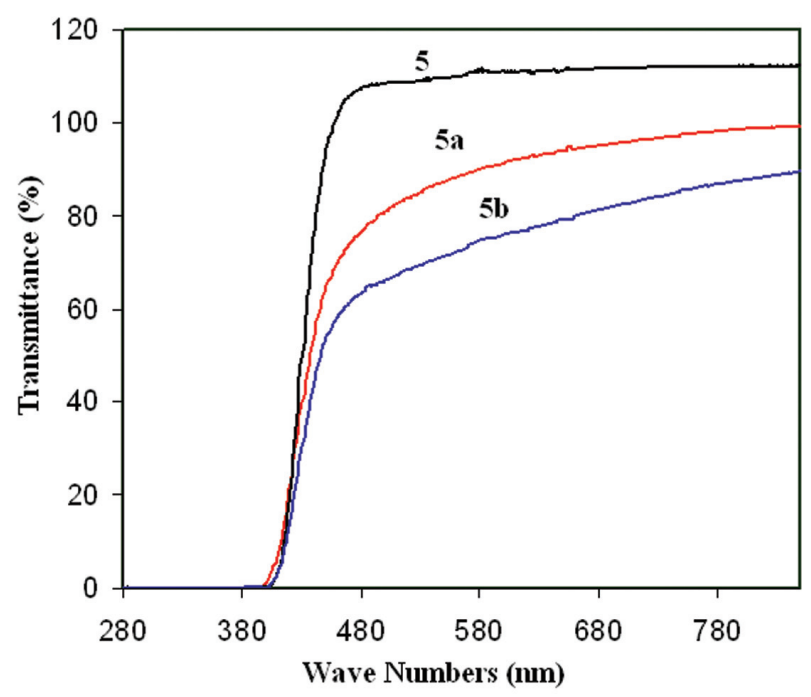

Fig. 5. UV-Vis spectra of PAI 5, PAI-nanocomposite films $\mathbf{5 a}$ and $\mathbf{5 b}$

\section{Thermogravimetric analysis}

The thermal properties of PAI-nanocomposite films containing 10 and $20 \mathrm{wt} . \%$ clay platelets and neat PAI were investigated by using TGA andDTG in nitrogen atmosphere at a rate of heating of $10^{\circ} \mathrm{C} / \mathrm{min}$, and thermal data are summarized in Table 1. These samples exhibited good resistance to thermal decomposition, up to $185-275^{\circ} \mathrm{C}$ in nitrogen, and began to decompose gradually above this temperature. $\mathrm{T}_{5}$ for these polymers ranged from $185-275^{\circ} \mathrm{C}$ and $\mathrm{T}_{10}$ for them ranged from $205-325^{\circ} \mathrm{C}$, and residual weights at
$600{ }^{\circ} \mathrm{C}$ ranged from 51.2 and $57.8 \%$ in nitrogen, respectively. Incorporation of organoclay into the PAI matrix also enhanced the thermal stability of the nanocomposites. Figure 6 shows the TGA thermograms of PAI-nanocomposites under nitrogen atmosphere. Thus, we can speculate that interacting PAIs chains between the clay layers serve to improve the thermal stability of nanocomposites. The addition of organoclay in polymeric matrix can significantly improve the thermal stability of PAI.

\section{Table 1}

Thermal behavior and water uptake of neat PAI 5 and PAI-nanocomposite films $5 a \& 5 b$

\begin{tabular}{ccccc}
\hline \hline Polyimide & $\begin{array}{c}\mathrm{T}_{5} \\
\left({ }^{\circ} \mathrm{C}\right)^{\mathrm{a}}\end{array}$ & $\begin{array}{c}\mathrm{T}_{10} \\
\left({ }^{\circ} \mathrm{C}\right)^{\mathrm{b}}\end{array}$ & Char yield $^{\mathrm{c}}$ & $\begin{array}{c}\text { Water } \\
\text { uptake } \\
(\%)^{\mathrm{d}}\end{array}$ \\
\hline $\mathbf{5}$ & 185 & 205 & 51.2 & 7.40 \\
$\mathbf{5 a}$ & 190 & 225 & 52.3 & 5.40 \\
$\mathbf{5 b}$ & 275 & 325 & 57.8 & 1.14 \\
\hline \hline
\end{tabular}

a,b Temperature at which $5 \%$ and $10 \%$ weight loss was recorded by TGA at heating rate of $10{ }^{\circ} \mathrm{C} / \mathrm{min}$ in $\mathrm{N}_{2}$ respectively. dPercentage weight of material left undecomposed after TGA analysis $600^{\circ} \mathrm{C}$.

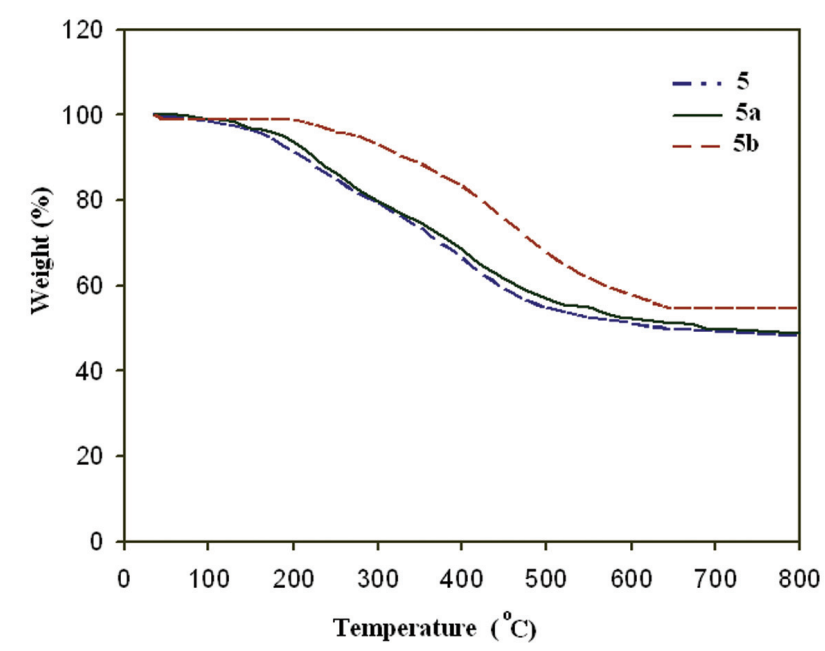

Fig. 6. TGA thermograms of neat PAI 5 and PAInanocomposite films $\mathbf{5} \mathbf{a}$ and $\mathbf{5 b}$

\section{Water absorption measurements}

The results showed maximum water uptake for the pure poly(amide-imide) $(7.40 \%)$ with monotonic but asymptotic decreased thereafter 
(Table 1). The exposure of polar groups to the surface of polymer where water molecules develop secondary bond forces with these groups. The clay platelets obviously restrict the access of water to the hydrogen-bonding sites on the polymer chains. The weight gain by the films gradually decreased as the clay content was increased. It is apparently due to the mutual interaction between the organic and inorganic phases. This interaction resulted in the lesser availability of polar groups to interact with water. Secondly, the impermeable clay layers mandate a tortuous pathway for a permeant to transverse the nanocomposite. The enhanced barrier characteristics, chemical resistance and reduced solvent uptake PAI-nanocomposites all benefit from the hindered diffusion pathways through the nanocomposite [26].

\section{CONCLUSION}

The PAI-nanocomposites were successfully prepared using solution intercalation method. The structure and the uniform dispersion of organoclay throughout the PAI matrix were confirmed by FTIR, XRD and SEM analyses. The optical clarity and water absorption property of PAI-nanocomposites were decreased significantly with increasing the organoclay contents in PAI matrix. On the contrary, the thermal stability of PAI-nanocomposites were increased significantly with increasing the organoclay contents in PAI matrix. The enhancements in the thermal stability of the nanocomposites films $\mathbf{5 a}$ and $\mathbf{5 b}$ caused by introducing organoclay may be due to the strong interactions between polymeric matrix and organoclay generating good intercalation and dispersion of clay platelets in the PAI matrix.

\section{REFERENCES}

[1] E. P. Giannelis, Polymer layered silicate nanocomposites, Adv. Mater. 8, 29-35 (1996).

[2] Y. Yano, A. Usuki, T. Kurauchi, O. Kamigato, Synthesis and properties of polyimide-clay hybrid, J. Polym. Sci. Part Polym. Chem. 31, 2493-2498 (1993).
[3] S. Zulfiqar, Z. Ahmad, M. Ishaq, S. Saeed, M. I. Sarwar, Thermal and mechanical properties of SEBS-g-MA based inorganic composite materials, J. Mater. Sci. 42, 93-100 (2007).

[4] M. Sikka, L. N. Cerini, S. S. Ghosh, K. I. Winey, Melt intercalation of polystyrene in layered silicates, J. Polym. Sci. Part B: Polym. Phys. 34, 1443-1449 (1996).

[5] R. Xu, E. Manias, A.J. Snyder, J. Runt, New biomedical poly(urethane urea)-layered silicate nanocomposites, Macromolecules 34, 337-339 (2001).

[6] A. Kausar, S. Zulfiqar, S. Shabbir, M. Ishaq, M.I. Sarwar, Mechanical properties of functionalized SEBS based inorganic hybrid materials, Polym. Bull. 59, 457-468 (2007).

[7] N. Bibi, M. I. Sarwar, M. Ishaq, Z. Ahmad, Mechanical and thermal properties of nano-composites of poly(vinyl chloride) and co-poly(vinyl chloride-vinyl alcohol-vinyl acetate) with montmorillonite, Polym. Polym. Compos. 15, 313-315 (2007).

[8] S. Zulfiqar, M. I. Sarwar, Scr. Mechanical and thermal behavior of clay-reinforced aramid nanocomposite materials, Mater 59, 436-439 (2008).

[9] T. D. Fornes, P. J. Yoon, D. L. Hunter, H. Keskkula, D. R. Paul, Effect of organoclay structure on nylon 6 nanocomposite morphology and properties, Polymer 43, 5915-5933 (2002).

[10] G. M. Chen, Y. M. Ma, Z. N. Qi, Preparation of polystyrene/toluene-2,4-di-isocyanate-modified montmorillonite hybrid, J. Appl. Polym. Sci. 77, 2201-2205 (2000).

[11] Kh. Faghihi, M. Shabanian, M. Hajibeygi, Optically active and organosoluble poly(amide-imide)s derived from N,N'-(Pyromellitoyl)bis-L-histidine and various diamines: synthesis and characterization, Macromol. Res. 17, 912-918 (2009).

[12] Kh. Faghihi, M. Hajibeygi, M. Shabanian, Photosensitive and optically active poly(amide-imide) s based on $N, N$-(pyromellitoyl)-bis-L-amino acid and dibenzalacetone moiety in the main chain: synthesis and characterization, J. Macromol. Sci. Part A: Pure Appl. Chem. 47, 144-153 (2010).

[13] M. K. Ghosh, K. L. Mittal, Polyimide: Fundamental and Applications, Dekker, New York, 1996.

[14] D. J. Liaw, B. Y. Liaw, Synthesis and characterization of new polyamide-imides containing pendent adamantyl groups, Polymer 42, 839-845 (2001).

[15] Q. Zhang, S. Li, W. Li, S. Zhang, Synthesis and properties of novel organosoluble polyimides derived from 1,4-bis[4-(3,4-dicarboxylphenoxy)]- 
triptycene dianhydride and various aromatic diamines, Polymer 48, 6246-6253 (2007).

[16] Q. Zhang, G. Chen, S. Zhang, Synthesis and properties of novel soluble polyimides having a spirobisindane-linked dianhydride unit, Polymer 48, 2250-2256 (2007)

[17] A. Saxena, V. L. Rao, P. V. Prabhakaran, K. N. Ninan, Synthesis and characterization of polyamides and poly(amide-imide)s derived from 2,2-bis(4-aminophenoxy)benzonitrile, Eur. Polym. J. 39, 401-405 (2003).

[18] C. P. Yang, Y. P. Chen, E. M. Woo, Thermal behavior of 1,4-bis(4-trimellitimido-2-trifluoromethyl phenoxy)benzene (DIDA) solvated with polar organic solvents and properties of DIDA-based poly(amide-imide)s, Polymer 45, 5279-5293 (2004).

[19] D. J. Liaw, W. H. Chen, High glass transitions of novel organosoluble polyamide-imides based on noncoplanar and rigid diimide-dicarboxylic acid, Polym. Degrad. Stab. 91, 1731-1739 (2006).

[20] S. Mallakpour, M. Kolahdoozan, Preparation of new poly(amide-imide)s with chiral architectures via direct polyamidation reaction, J. Appl. Polym. Sci. 104, 1248-1254 (2007).

[21] Kh. Faghihi, M. Hajibeygi, M. Shabanian, Synthesis and properties of novel flame-retardant and thermally stable poly(amide-imide)s from $N, N$ '(bicyclo[2,2,2]oct-7-ene-tetracarboxylic)-bis-Lamino acids and phosphine oxide moiety by two different methods, Macromol. Res. 17, 739-745 (2009).

[22] Kh. Faghihi, M. Hajibeygi, M. Shabanian, Synthesis and properties of new photosensitive and chiral poly(amide-imide)s based on bicyclo[2,2,2]oct-7ene-2,3,5,6-tetracarboxylic diimide and dibenzalacetonemoieties in the main chain, Polym. Int. 59, 218-226 (2010).

[23] S. Mallakpour, A. R. Hajipour, S. Habibi, Synthesis of novel poly(amide-imide)s containing trimellitylimido-DL/L-alanine moieties via direct polycondensation, J. Appl. Polym. Sci. 80, 13121318 (2001).

[24] S. Zulfiqar, M. I. Sarwar, Inclusion of aramid chains into the layered silicates through solution intercalation route, J. Incl. Phenom. Macrocycl. Chem. 62, 353-361 (2008).

[25] P. S. G. Krishnan, A. E. Wisanto, S. Osiyemi, C. Ling, Synthesis and properties of BCDA-based polyimide-clay nanocomposites, Polym. Inter. 56, 787-795 (2007).

[26] R. K. Bharadwaj, Modeling the barrier properties of polymer-layered silicate nanocomposites, Macromolecules 34, 9189-9192 (2001). 
